\title{
Infection of Henneguya sp. on the gills of Metynnis lippincottianus from Curiaú River, in eastern Amazon region (Brazil)
}

\author{
Infecção de Henneguya sp. nas brânquias de Metynnis lippincottianus do rio \\ Curiaú, na region da Amazônia oriental (Brasil) \\ Abthyllane Amaral de Carvalho1; Marcela Nunes Videira2; Luana Silva Bittencourt²; Priscila Gomes de Araújo²; \\ Roger Leomar da Silva Ferreira²; José Carlos Tavares³; Edilson Rodrigues Matos ${ }^{4}$ (D)

\footnotetext{
${ }_{1}^{1}$ Programa de Pós-graduação em Biologia de Agentes Infecciosos e Parasitários, Universidade Federal do Pará, Belém, Pará, Brasil

${ }^{2}$ Laboratório de Morfofisiologia e Sanidade Animal, Universidade do Estado do Amapá, Macapá, Amapá, Brasil

${ }^{3}$ Laboratório de Pesquisa em Fármacos, Universidade Federal do Amapá, Macapá, Amapá, Brasil
} \\ ${ }^{4}$ Laboratório de Pesquisa Carlos Azevedo, Instituto de Saúde e Produção Animal, Universidade Federal Rural do Pará, Belém, Pará, Brasil
}

How to cite: Carvalho AA, Videira MN, Bittencourt LS, Araújo PG, Ferreira RLS, Tavares JC et al. Infection of Henneguya sp. on the gills of Metynnis lippincottianus from Curiaú River, in eastern Amazon region (Brazil). Braz J Vet Parasitol 2020; 29(3): e003320. https://doi.org/10.1590/S1984-29612020037

\begin{abstract}
Infection of fish gills by Henneguya causes greater contact between the secondary gill lamellae, thereby giving rise to decreased absorption surface area at the end of the filaments. This ectoparasite can cause damages on the gills infected fish. In the present study, fresh gills of Metynnis lippincottianus were analyzed using optical microscopy techniques. The myxoporean Henneguya sp. was found to be infecting $80 \%$ of the gills of this host fish. Presence of this parasite caused hyperplasia and fusion of the gill lamellae, but without inflammation in the parasitized organ.
\end{abstract}

Keywords: Myxosporea, fish, parasitosis.

\section{Resumo}

A infecção de Henneguya nas brânquias de peixes causam o maior contato entres as lamelas branquiais secundárias. Provoca diminuição da superfície de absorção na extremidade dos filamentos, podendo ocasionar danos as brânquias dos peixes infectados. Neste estudo foram analisadas a fresco e com técnicas de microscopia de luz as brânquias de Metynnis lippincottianus. Foi determinada a presença de mixosporídeos Henneguya sp. infectando $80 \%$ das brânquias dos peixes hospedeiros. A presença desse ectoparasito causou hiperplasia e fusão das lamelas branquiais, porém sem inflamação no órgão parasitado.

Palavras-chave: Myxosporea, peixe, parasitoses. 
Metynnis lippincottianus Cope, 1870, a fish that is popularly known as pratinha, is widely distributed in the rivers of the Brazilian and French Guiana basins system. It belongs to the family Serrasalmidae and feeding basically on seeds and phytoplankton. It is characterized by silver color and has commercial importance for the aquarium trade and for the food chain, within which it occupies the second trophic level (Ota, 2015).

The subphylum Myxozoa encompasses the cnidarians, a group that parasitizes both vertebrates and invertebrates (Teixeira et al., 2018). This subphylum includes more than 2400 species, classified into 17 families and 64 genera (Zhang, 2011; Fiala et al., 2015). The genus Henneguya Thélohan (1892) comprises more than 200 species, among which 55 have been described as occurring in Brazil, and 16 have been reported in the Amazon basin (Zatti et al., 2018). Regarding morphology, this genus has two prolonged valves and each of these contains a polar capsule with a spiral filament and a sporogenic cell, usually binucleated, which forms the spores of this genus (Matos et al., 2001).

According Mólnar (2002), Henneguya sp. infection on fish gills causes greater contact between the secondary gill lamellae, thereby decreasing the absorption surface area at the end of the filaments, due to gill hyperplasia and hypertrophy. Species-level identification for myxosporeans based only on spore morphology and histopathology should be assessed with caution, since multiple reported species can occur in the same tissue/organ (Stilwell et al., 2020).

The fish gills constitute the first contact with the external environment, and therefore they are easily damaged by parasitic infections. These infections affect the main functions of the gills, such as osmoregulation, breathing and excretion. In addition, this organ can be used as a sentinel for parasitism levels, based on histopathological changes, respiratory disorders and electrolyte imbalances (Flores-Lopes \& Thomaz, 2011).

Given the scarce studies relating to the Curiaú river basin, state of Amapá, Brazil, on myxosporeans in fish, the main aim of the present study was to evaluate the histopathological damage caused by high levels of infection on the gills of M. lippincottianus, caused by Henneguya sp.

Thirty specimens of M. lippincottianus were caught in the Curiaú river floodplain, in municipality of Macapá $\left(0^{\circ} 08^{\prime} \mathrm{N}, 51^{\circ} 02^{\prime} \mathrm{W}\right)$. The hosts were collected and transported alive, in thermal boxes with the aid of a battery-operated pump for aeration, to the Laboratory of Morphophysiology and Animal Health (LABMORSA) of the University of the State of Amapá (UEAP), located in Macapá-AP. In the laboratory, they were placed in aquariums containing water from their habitat, which were equipped with an electric pump and filter, until the time of parasitological analysis.

At the beginning of the analysis, the fish were desensitized by means of medullary sectioning and biometric data such as total length $(\mathrm{cm})$ and weight $(\mathrm{g})$ were measured. Then, the operculum was cut to expose the gills. Macroscopically, no signs of parasitism (presence of cysts) were observed. Small fragments of the gills were removed, placed between a slide and cover slip and analyzed under an optical microscope.

The analysis on these slides showed the presence of parasitism (cysts). Fragments of these tissues/organs were removed and fixed in Davidson's solution (neutral formalin, acetic acid, 95\% alcohol and distilled water) for 24 hours. They were then processed for embedding in paraffin and histological slices of thickness $5 \mu m$ were cut. These thin sections were stained using hematoxylin and eosin (H\&E) and a special Ziehl-Neelsen (ZN) technique at the Carlos Azevedo Research Laboratory (LPCA) of the Federal Rural University of the Amazon (UFRA).

From the gill fragments that were placed between a slide and cover slip with a drop of water and observed under an optical microscope, the presence of parasite cysts could be seen. Cysts that had ruptured exhibited spores with morphological characteristics of the genus Henneguya. Out of the 30 specimens analyzed, 24 presented Henneguya sp., i.e. with prevalence of $80 \%$.

Staining with hematoxylin-eosin $(\mathrm{H}-\mathrm{E})$ was enough to show the presence of some parasite cysts. However, use of the ZN technique enhanced the visualization of the cysts, such that cysts that had not been observed using H\&E now became marked.

Stilwell et al. (2020), showed the importance of marking specific spore characteristics using various immunohistochemistry techniques, including Ziehl-Neelsen used in this work, of Myxozoa (Cnidaria) spores, as structural of mature myxospores in histological sections, corroborating with our observations in the parasite-host interaction.

The spores of Henneguya sp. $(n=30)$ found in gills filaments of M. lippincottianus showed $67.4 \pm 6.8 \mu \mathrm{m}(57.8-73.1)$ of total length; $37.8 \pm 5.0 \mu \mathrm{m}(30.3-43.5)$ spore body length; $7.2 \pm 1.0 \mu \mathrm{m}(5.3-8.1)$ spore width; $29.9 \pm 4.8 \mu \mathrm{m}$ (21.9 - 33.8) tail length; $22.3 \pm 1.7 \mu \mathrm{m}$ (18.9 - 23.4) of polar capsule length; and $2.5 \pm 0.9 \mu \mathrm{m}$ (1.6-3) of polar capsule width. 
The total length and spore body length of Henneguya sp. found in this study was closest of Henneguya sp. found by Figueredo et al. (2020) in Metynnis hypsauchen Müller \& Troschel, 1844 with $61.9 \pm 1.25 \mu \mathrm{m}$ and $38.2 \pm 0.8 \mu \mathrm{m}$, respectively. The tail length $(29.5 \pm 0.7)$ and the polar capsule width $(2.6 \pm 0,08 \mu \mathrm{m})$ of Henneguya paraensis described by Velasco et al. (2016) in Cichla temensis Humboldt, 1821 are similar to Henneguya sp. of this study. The polar capsule length of Henneguya sp. $(22.3 \pm 1.7 \mu \mathrm{m})$ was the morphometric data that most distanced itself from all species of Henneguya spp. described in Table 1.

Table 1. Morphological comparison $(\mu \mathrm{m})$ of mature spores of Henneguya sp. with species described from Amazon Brazilian fish hosts.

\begin{tabular}{|c|c|c|c|c|c|c|c|c|}
\hline Parasite & TL & BL & BW & TAL & PCL & PCW & Sities & Hosts \\
\hline $\begin{array}{l}\text { Henneguya sp1. } \\
\text { (present study) }\end{array}$ & $67.43 \pm 6.86$ & $37.87 \pm 5.02$ & $7.2 \pm 1.05$ & $29.91 \pm 4.88$ & $22.3 \pm 1.67$ & $2.47 \pm 0.83$ & $\begin{array}{c}\text { Curiau } \\
\text { River/AP } \\
\text { (Brazil) }\end{array}$ & $\begin{array}{c}\text { Metynnis } \\
\text { lippincottianus }\end{array}$ \\
\hline $\begin{array}{l}\text { Henneguya sp2. } \\
\text { (Figueredo et al., } \\
\text { 2020) }\end{array}$ & $61.9 \pm 1.25$ & $38.2 \pm 0.8$ & $5.8 \pm 0,45$ & $23.7 \pm 0.5$ & $6,1 \pm 0.15$ & $1.8 \pm 0.1$ & $\begin{array}{l}\text { Capim } \\
\text { River/PA } \\
\text { (Brazil) }\end{array}$ & $\begin{array}{c}\text { Metynnis } \\
\text { hypsauchen }\end{array}$ \\
\hline $\begin{array}{c}\text { Henneguya } \\
\text { adherens } \\
\text { (Azevedo \& } \\
\text { Matos, 1995) }\end{array}$ & $32.3 \pm 2.2$ & $12.4 \pm 1.65$ & $5.8 \pm 0.7$ & $20.5 \pm 1.85$ & $3.1 \pm 0.35$ & $1.2 \pm 0.3$ & $\begin{array}{c}\text { Amazon } \\
\text { River/PA } \\
\text { (Brazil) }\end{array}$ & $\begin{array}{c}\text { Acestrorhynchus } \\
\text { falcatus }\end{array}$ \\
\hline $\begin{array}{c}\text { Henneguya } \\
\text { aequidens } \\
\text { (Videira et al., } \\
\text { 2015) }\end{array}$ & $41 \pm 1.5$ & $15 \pm 0.9$ & $6 \pm 0.8$ & $27 \pm 0.6$ & $3 \pm 0.3$ & $3 \pm 0.3$ & $\begin{array}{l}\text { Peixe-boi } \\
\text { River/PA/ } \\
\text { (Brazil) }\end{array}$ & $\begin{array}{c}\text { Aequidens } \\
\text { plagiozonatus }\end{array}$ \\
\hline $\begin{array}{c}\text { Henneguya } \\
\text { paraensis } \\
\text { (Velasco et al., } \\
\text { 2016) }\end{array}$ & $42.3 \pm 0.65$ & $12.8 \pm 0.42$ & $8.6 \pm 0.32$ & $29.5 \pm 0.73$ & $7.4 \pm 0.16$ & $2.6 \pm 0.08$ & $\begin{array}{c}\text { Tocantins } \\
\text { River/PA } \\
\text { (Brazil) }\end{array}$ & Cichla temensis \\
\hline $\begin{array}{c}\text { Henneguya } \\
\text { rhamdia } \\
\text { (Matos et al., } \\
\text { 2005) }\end{array}$ & $50 \pm 1.8$ & $13.1 \pm 1.1$ & $5.2 \pm 0.5$ & $36.9 \pm 1.6$ & $4.7 \pm 0.4$ & $1.1 \pm 0.2$ & $\begin{array}{c}\text { Peixe-boi } \\
\text { River/PA } \\
\text { (Brazil) }\end{array}$ & Rhamdia quelen \\
\hline $\begin{array}{c}\text { Henneguya } \\
\text { astyanax } \\
\text { (Vital et al., 2003) }\end{array}$ & $47.8 \pm 0.71$ & 15.2 & $5.7 \pm 0.71$ & 32.6 & $5.0 \pm 0.13$ & $1.5 \pm 0.07$ & $\begin{array}{c}\text { Amazon } \\
\text { River/PA } \\
\text { (Brazil) }\end{array}$ & Astyanax keithi \\
\hline $\begin{array}{l}\text { Henneguya } \\
\text { malabarica } \\
\text { (Azevedo \& } \\
\text { Matos, 1996) }\end{array}$ & $28.3 \pm 1.6$ & $12.6 \pm 0.65$ & 8.6 & $17.1 \pm 1.35$ & $3.7 \pm 0.65$ & $1.8 \pm 0.3$ & $\begin{array}{c}\text { Amazon } \\
\text { River/PA } \\
\text { (Brazil) }\end{array}$ & $\begin{array}{c}\text { Hoplias } \\
\text { malabaricus }\end{array}$ \\
\hline $\begin{array}{c}\text { Henneguya } \\
\text { santarensis } \\
\text { (Naldoni et al., } \\
\text { 2018) }\end{array}$ & $31.9 \pm 3$ & $10.8 \pm 0.5$ & $4.3 \pm 0.3$ & $21 \pm 3.1$ & $4.6 \pm 0.4$ & $1.4 \pm 0.2$ & $\begin{array}{c}\text { Tapajós } \\
\text { River/PA } \\
\text { (Brazil) }\end{array}$ & $\begin{array}{c}\text { Phractocephalus } \\
\text { hemioliopterus }\end{array}$ \\
\hline $\begin{array}{c}\text { Henneguya } \\
\text { tucunarei } \\
\text { (Zatti et al., 2018) }\end{array}$ & $43.8 \pm 6.75$ & $14 \pm 1.8$ & $6.1 \pm 1.45$ & $28.1 \pm 8$ & $3.4 \pm 1.05$ & $2 \pm 0.65$ & $\begin{array}{c}\text { Tapajós } \\
\text { River/PA } \\
\text { (Brazil) }\end{array}$ & $\begin{array}{c}\text { Cichla } \\
\text { monoculus }\end{array}$ \\
\hline $\begin{array}{c}\text { Henneguya } \\
\text { tapajoensis } \\
\text { (Zatti et al., 2018) }\end{array}$ & $54.6 \pm 7.5$ & $16.4 \pm 2.3$ & $7 \pm 1,8$ & $39 \pm 7.4$ & $4.2 \pm 1.05$ & $2.1 \pm 0.65$ & $\begin{array}{c}\text { Tapajós } \\
\text { River/PA } \\
\text { (Brazil) }\end{array}$ & Cichla pinima \\
\hline
\end{tabular}

AP: Amapá state, PA: Pará state, TL: total length, BL: body length, BW: body width, TAL: tail length, PCL: polar capsule length, PCW: polar capsule width.

Regarding the spore body morphology of Henneguya sp. in present study, it showed ellipsoidal shape, as well the Henneguya paraensis (Velasco et al., 2016) in Cichla temensis Humboldt, 1821, but differentiated by the occupation of the polar capsule in the sporoplasm. 
Most species of the genus Henneguya do not cause notable diseases in their hosts. However, some are pathogenic and infection with these species can cause mortality in fish populations. If the parasites replicate at high intensity in the gills, this will cause respiratory failure (Figueredo et al., 2020). The genus Henneguya usually develops in the form of cysts of histozoic nature. The description of this genus includes additional characteristics, such as host identification and level of tissue tropism (Matos et al., 2001).

In the present study, the gills of $M$. lippincottianus were found to present large numbers of cysts of the genus Henneguya, as shown in Figure 1a. The high numbers of Henneguya sp. cysts in fish gills may be directly related to the feeding habits and biological and physiological behavior of the fish species affected, since these factors can affect the structure of the parasite community (Carvalho \& Tavares-Dias, 2017).
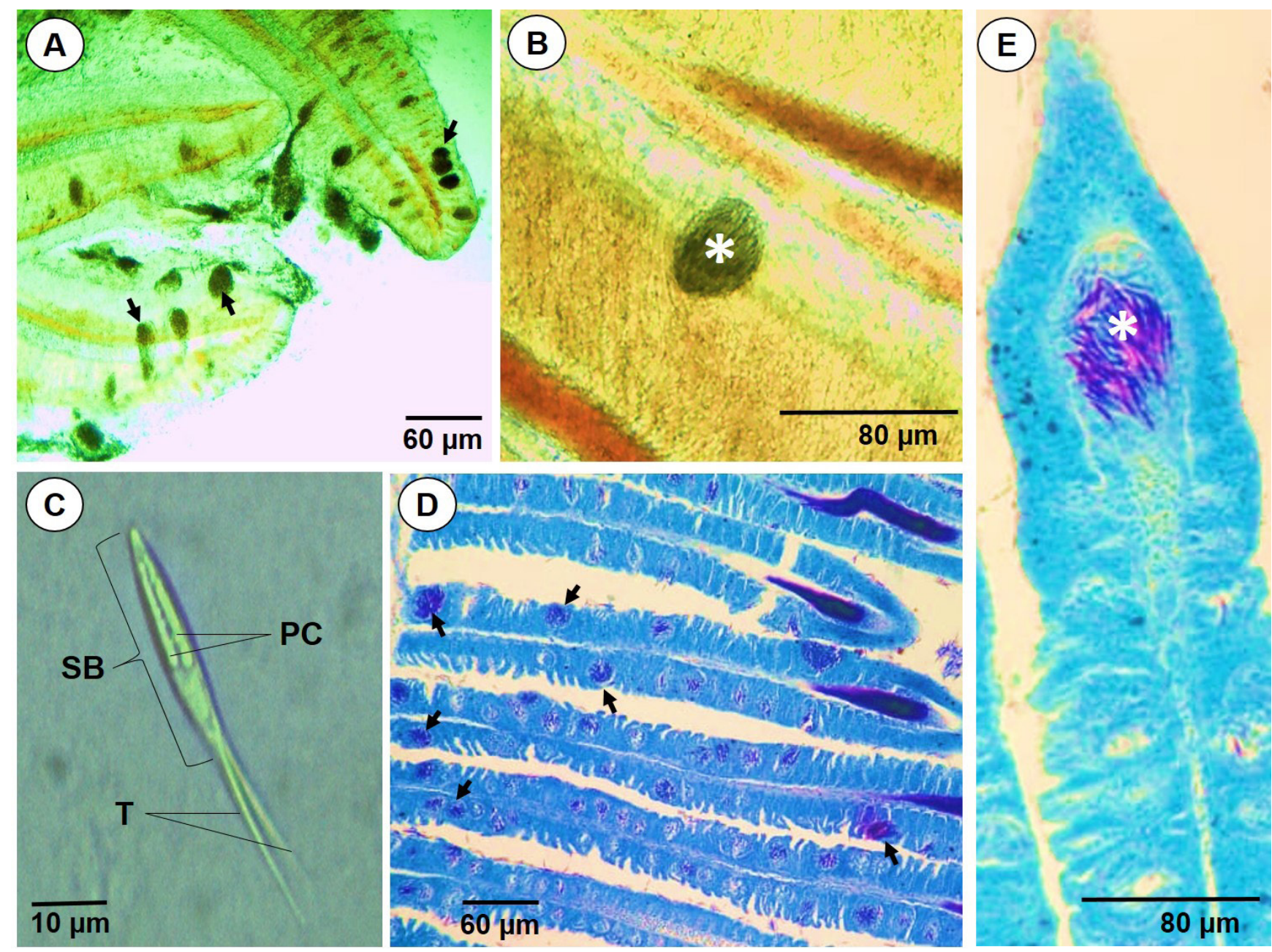

Figure 1. Cysts of Henneguya sp. in Metynnis lippincottianus: A - cysts (arrows) observed freshly on the gill filaments under optical microscopy (bar $20 \mu \mathrm{m}$ ); B - cyst (asterisk) on the gill filament (bar $20 \mu \mathrm{m})$; C - spore of Henneguya sp. (bar $10 \mu \mathrm{m})$, SB: spore body, PC: polar capsule, T: tail; D - cysts (arrows) of interlamellar type associated with hyperplasia and secondary lamellar fusion (bar $20 \mu \mathrm{m}) ; \mathrm{E}$ - cysts (asterisk) inside the main lamellae (bar $20 \mu \mathrm{m})$.

Gills are the primary site of nitrogenous waste excretion and species of Henneguya spp. have different way to interaction with these structures and can resulting in different levels of disease (Mólnar, 2002). In Phractocephalus hemioliopterus Bloch \& Schneider, 1801, H. santarensis caused compression, deformation and fusion of adjacent lamellae (Naldoni et al., 2018), while Henneguya astyanax caused in Astyanax keithi Géry et al., 1996, surrounding tissues, moderate gill epithelial cell hyperplasia and a mild mononuclear inflammatory infiltrate within the interstitium of the gill (Vita et al., 2003).

The fresh and histological analyses on our samples showed that the cysts were surrounded by a thin layer of connective tissue (Figure 1c), with an enlarged cyst inside the main lamellae (Figure 1d), which led to slight compression of the gill filaments. No inflammation of the parasitized host tissue was observed, as was previously 
described in relation to the gills of Arapaima gigas Schinz, 1822; parasitized with cysts of Henneguya arapaima (Feijó et al., 2008).

While some parasite species may even develop in a filamental or lamellar location depending on fish size, plasmodium size and intensity of infection, species of Henneguya sp. can adapted to epithelium, cartilage, connective tissue or endothelium have not been found to develop primarily in other tissues, their possible occurrence in other tissues is the result of secondary host reaction (Mólnar, 2002).

Velasco et al. (2016) reported that the gills of Cichla temensis Humboldt, 1821 presented cysts of Henneguya paraensis cysts with thin layers of connective tissue and slight compression of the gill filaments, since the cysts grew adjacent to the filaments. Henneguyosis in gills of Metynnis hypsauchen Müller \& Troschel, 1844 was related by Figueredo et al. (2020), causing lesions associated to ischemic necrosis, compromising drastically the host's respiratory system.

Histopathological analysis showed that the secondary lamellae had become fused, and that hyperplasia and intraepithelial cysts were present in the primary lamella, due to the numerous cysts. This had previously been reported by Velasco et al. (2015) in relation to infection by Henneguya sp. in the gills of Hypophthalmus marginatus Valenciennes, 1840. Henneguya sp. has high specificity for its host, and its parasitic action can cause structural damage and, in some cases, the death of its host. It can also cause infertility when located in the sexual organs (Matos et al., 2001).

The fusion of the lamellae and hyperplasia of the gill epithelium caused by Henneguya sp. was also previously diagnosed in Oreochromis niloticus Linnaeus, 1758; with lesions that compromised the lamellar structures (Teixeira et al., 2018).

The high quantities of Henneguya sp. that were observed in the form of interlamellar cysts in the gills of M. lippincottianus, through special staining techniques under an optical microscope, notably impaired the gill structures such that consequent death of the host became a possibility.

\section{Acknowledgements}

The authors would like to thank to Coordenação de Aperfeiçoamento de Pessoal de Nível Superior (CAPES) for partial financial, UNIFAP - CAPES - Edital 20/2018 PVNS 947363P - Ciências Ambientais and to Conselho Nacional de Desenvolvimento Científico e Tecnológico (CNPq) Edital 06/2019 PQ 310068/2019-3 for the financial support given to professor Edilson Rodrigues Matos.

\section{References}

Azevedo C, Matos E. Henneguya adherens n. sp. (Myxozoa, Myxosporea), parasite of the Amazonian fish, Acestrorhynchus falcatus. J Eukaryot Microbio/ 1995; 42(5): 515-518. http://dx.doi.org/10.1111/j.1550-7408.1995.tb05898.x. PMid:7581326.

Azevedo C, Matos E. Henneguya malabarica sp. nov. (Myxozoa, Myxobolidae) in the Amazonian fish Hoplias malabaricus. Parasitol Res 1996; 82(3): 222-224. http://dx.doi.org/10.1007/s004360050099. PMid:8801553.

Carvalho AA, Tavares-Dias M. Diversity of parasites in Cichlasoma amazonarum Kullander, 1983 during rainy and dry seasons in eastern Amazon (Brazil). J Appl Ichthyology 2017; 33(6): 1178-1183. http://dx.doi.org/10.1111/jai.13451.

Feijó MM, Arana S, Ceccarelli PS, Adriano EA. Light and scanning electron microscopy of Henneguya arapaima n. sp. (Myxozoa: Myxobolidae) and histology of infected sites in pirarucu (Arapaima gigas: Pisces: Arapaimidae) fromthe Araguaia River, Brazil. Vet Parasitol 2008; 157(1-2): 59-64. http://dx.doi.org/10.1016/j.vetpar.2008.06.009. PMid:18771855.

Fiala I, Bartošová-Sojková P, Whipps CM. Classification and phylogenetics of Myxozoa. In: Okamura B, Gruhl A, Bartholomew JL, editors. Myxozoan evolution, ecology and development. Cham: Springer; 2015. p. 85-110. http://dx.doi.org/10.1007/978-3-31914753-6_5.

Figueredo RTA, de Oliveira JEF, Vilhena MDPSP, Berredo J, Santos WJPD, Matos E, et al. Henneguyosis in gills of Metynnis hypsauchen: an Amazon freshwater fish. J Parasit Dis 2020; 44(1): 213-220. http://dx.doi.org/10.1007/s12639-019-01183-7. PMid:32174727.

Flores-Lopes F, Thomaz AT. Histopathologic alterations observed in fish gills as a tool in environmental monitoring. Braz J Biol 2011; 71(1): 179-188. http://dx.doi.org/10.1590/S1519-69842011000100026. PMid:21437416.

Matos ER, Corral L, Matos P, Casal G, Azevedo C. Incidência de parasitas do Phylum Myxozoa (Sub-reino Protozoa) em peixes da região amazônica, com especial destaque para o gênero Henneguya. Rev Cienc Agra 2001; 36: 83-99. http://dx.doi.org/10.1590/ S1413-95962002000500010. 
Matos E, Tajdari J, Azevedo C. Ultrastructural studies of Henneguya rhamdia n. sp. (Myxozoa) a parasite from the Amazon teleost fish, Rhamdia quelen (Pimelodidae). J Eukaryot Microbio/ 2005; 52(6): 532-537. http://dx.doi.org/10.1111/j.1550-7408.2005.00063.x. PMid:16313446.

Mólnar K. Site preference of fish myxosporeans in the gill. Dis Aquat Organ 2002; 48(3): 197-207. http://dx.doi.org/10.3354/ dao048197. PMid:12033706.

Naldoni J, Maia AA, Correa LL, Silva MR, Adriano EA. New myxosporeans parasitizing Phractocephalus hemioliopterus from Brazil: morphology, ultrastructure and SSU-rDNA sequencing. Dis Aquat Organ 2018; 128(1): 37-49. http://dx.doi.org/10.3354/dao03210. PMid:29565252.

Ota RP. Revisão taxonômica e filogenia morfológica de Metynnis Cope, 1878 (Characiformes: Serrasalmidae) [tese]. Manaus: Instituto Nacional de Pesquisas da Amazônia; 2015.

Stilwell JM, Griffin MJ, Rosser TG, Mohammed HH, Sidor IF, Camus AC. Insights into myxozoan composition and physiology revealed by histochemical properties of myxospores.J Fish Dis 2020; 43(3): 583-597. http://dx.doi.org/10.1111/jfd.13152. PMid:32202327.

Teixeira RJ, Eiras JC, Spadacci-Morena DD, Xavier JG, Lallo MA. Infecção das brânquias de tilápia do Nilo (Oreochromis niloticus) por Myxosporea. Pesq Vet Bras 2018; 38(6): 1085-1090. http://dx.doi.org/10.1590/1678-5150-pvb-4859.

Velasco M, Videira MN, Nascimento LCS, Matos P, Gonçalves EC, Matos E. Henneguya paraensis n. sp. (Myxozoa; Myxosporea), a new gill parasite of the Amazonian fish Cichla temensis (Teleostei: Cichlidae): morphological and molecular aspects. Parasitol Res 2016; 115(5): 1779-1787. http://dx.doi.org/10.1007/s00436-016-4916-6. PMid:26847632.

Velasco M, Videira MN, Sindeaux-Neto JL, Santos P, Sanches O, Matos P, et al. Infection by Henneguya sp. (Myxozoa) in the bone tissue of the gill filaments of the Amazonian catfish Hypophthalmus marginatus (Siluriformes). Braz J Vet Parasitol 2015; 24(3): 365-369. http://dx.doi.org/10.1590/S1984-29612015021. PMid:26331865.

Videira M, Velasco M, Azevedo R, Silva R, Gonçalves E, Matos P, et al. Morphological aspects of Henneguya aequidens n. sp. (Myxozoa: Myxobolidae) in Aequidens plagiozonatus Kullander, 1984 (Teleostei: Cichlidae) in the Amazon region, Brazil. Parasitol Res 2015; 114(3): 1159-1162. http://dx.doi.org/10.1007/s00436-014-4295-9. PMid:25573695.

Vital P, Corral L, Matos E, Azevedo C. Ultrastructural aspects of the myxosporean Henneguya astyanax n. sp. (Myxozoa: Myxobolidae), a parasite of the Amazonian teleost Astyanax keithi (Characidae). Dis Aquat Organ 2003; 53(1): 55-60. http://dx.doi.org/10.3354/ dao053055. PMid:12608569.

Zatti AS, Atkinson S, Maia AA, Bartholomew JL, Adriano EA. Novel Henneguya spp. (Cnidaria: Myxozoa) from cichlid fish in the Amazon basin cluster by geographic origin. Parasitol Res 2018; 117(3): 849-859. http://dx.doi.org/10.1007/s00436-018-5762-5. PMid:29374784.

Zhang ZQ. Animal biodiversity: An outline of higher-level classification and survey of taxonomic richness. Auckland, New Zealand: Magnolia press; 2011. 